\title{
The Influence of Perceived Organizational Support Toward The Employees' Turnover Intentions in Budget Hotel: A Case Study in Jakarta
}

\author{
Agus Riyadi ${ }^{1}$ \\ ${ }^{1}$ Sekolah Tinggi Pariwisata Trisakti, Jakarta, Indonesia \\ Email : ${ }^{1}$ agus.riyadi@stptrisakti.ac.id
}

\begin{abstract}
Turnover is a common problem for hospitality industry including hotel. There are many factors that could be the reason for employees to leave their organization. The objectives of this research are to find the relationship, the influence and the degree of the influence given by perceived organizational support toward the turnover intention. The questionnaire is distributed to 113 respondents of the staffs of budget hotels in Jakarta. The questionnaire consists of 17 questions of Perceived Organizational Support and 3 questions of Turnover Intention. The results showed that there is significant negative relationship $(r=-.542, p<0.01)$ between these two variables Moreover, perceived organizational support is proved to have influence $(R$-square $=.288)$ on turnover intention. The result of the $\boldsymbol{F}$-test also reassures that there is significant influence of perceived organizational support toward turnover intentions. It implies that if organization provides good support to the employees, they could reduce the turnover rate, as the employees will prefer to stay within the organization. From this study, the result can be used by the organization as one consideration for them in developing a method to stabilize the turnover rate in Budget Hotel, Jakarta.
\end{abstract}

Keywords - Perceived Organizational Support, Turnover Intention

\section{INTRODUCTION}

The hotel industry in Jakarta has also grown rapidly. New hotels have been constructed, and there has been an increased competition among the hotels.. Economic and corporate growth both domestically and internationally has failed to stimulate sufficient room night demand growth in the nation's capital. The highly volatile and competitive business environment has encouraged the hotel industry in Jakarta to be more practical in its employees' performance so as to provide a high standard of quality services to the customers. This inline with the environment moderate the strength influence of the relationship between business strategy and performance of hotels in Jakarta (Riyadi and Radzi, 2012: 184-94).

This, in combination with supply growth and the trading down of hotel tiers by corporates has led to panic selling of hotel rooms at reduced rates. As a service industry, the hotel's service quality is directly related to its staff quality that makes it relies to a considerable extent on human labor (Arunothaipipat, 2013 : 89). However, hotel industry is a labor-intensive industry and labor costs on goods and services produced are very high. It counts almost $40 \%$ on total expenses. Aside from the high costs for human labor, the hotel business in Thailand also has to face the problem of lack of workforce, especially the skilled one. Hence, human resource administration is one thing that hotel business put importance on (Lee \& Moreo in Limyothin \& Trichun, $2012: 23$ ).. To address this issue of human resource, the hotel business will try to decrease the intention to quit, increase work efficiency to achieve the organizational goals by increasing the quality of work life, perceived organizational structure, job satisfaction and organizational commitment (Gary \& Ligouri in Limyothin \& Trichun, $2012: 23$ ).

Based on table 1[4], the salary for 2017 have significant increase from 7,9\% to 8,7\% in hotel industry. This condition also has an impact on the worker's willingness to move on due to the attractive salary offerings on the new property. The employee turnover in the hospitality industry in Indonesia also high that averages as much as $200 \%$ to $300 \%$ (Demir, Çolakoğlu \& Güzel,2007 : 477). 
However, among all segments, it seems that large-scale hotels that are usually four to five-star hotels, have more advantages in human resource (HR) recruitment and development. This is based on the consideration that large-scale hotel usually can offer higher level of remuneration and welfare to attract the highly capable staff (Arunothaipipat, $2013: 89$ ).

\begin{tabular}{lcc} 
TABLE 1. FORECASTED ASEAN SALARY 2016-2017 \\
\hline Market & \multicolumn{2}{c}{ Overall Salary Increase Budgets } \\
\cline { 2 - 3 } & 2016 Actual & 2017 Planned \\
\hline Indonesia & $7.9 \%$ & $8.7 \%$ \\
\hline Thailand & $5.5 \%$ & $5.7 \%$ \\
\hline Malaysia & $5.5 \%$ & $5.6 \%$ \\
\hline Singapore & $4.2 \%$ & $4.4 \%$ \\
\hline Source: www.apac.aonhewitt.com (October/November 2016) [4]
\end{tabular}

The turnover of the employee, where the old employee resigned and the new employee came was quite significant and detectable. This problem is clearly shown by the Figure 1 where there is a significant increase of cumulative supply, demand and occupancy rate of hotel in Jakarta from 2016 to 2017. The supply in quarter one to three was $0.70 \%$ and it increased to $0.75 \%$ in quarter 4 . There could be many possible causes for this increase as turnover may occur for many different reasons. This data indicated that the number of new hotel developments will have an impact on employee job movements. However, based on the researcher's observation, this condition might be caused by the emerging competitive workplaces for employees during that time, such as new-built hotels, etc. that might offer better career path, better organization support, better organizational culture, better employee benefits, training, etc.

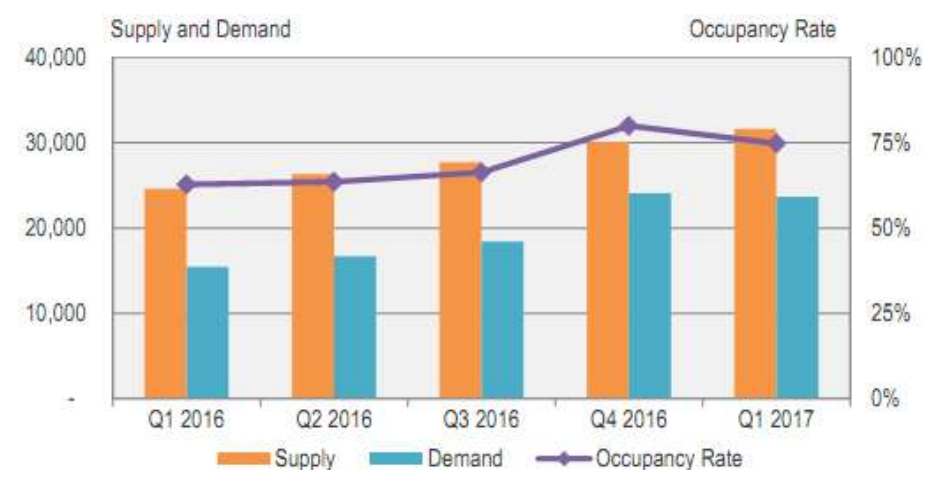

Fig. 1. Cumulative Supply, Demand, and Occupancy Rate of Hotel in Jakarta

Source: Colliers Quarterly (Q3.2017) [6]

Beside this significant increase of turnover rate that indicate the problem regarding turnover, researcher also found that some budget hotel employees who were still working in the organization had some plans to find another job or to leave the organization. In regard with these conditions, researcher would like to study about the turnover intention since employees typically make conscious decision before actually quitting their jobs(Barak, Nissly \& Levin in Amin \& Akbar, $2013: 663$ ) and according to Mobley in Shelton $(2013: 663)$, turnover intention is the final phase prior to actual turnover.

Actually, turnover occurs for many different reasons. It could be because a new job attracts employees and pull them to leave the old one, but could also because the employees are pushed to leave job due to the dissatisfaction in their present workplace or by domestic circumstances (Shamsuzzoha and Shumon, 2010:65). For the second reason mentioned, it is commonly known as the push factors. Push factors are aspects that push the employee towards the exit door. In the literature, it is also called controlled factors because the factors are internal and can be controlled by organizations. This push factor can be classified into organizational factors, attitude factors, and organizational commitment (Shah et al., 2010:170).

These push factors are indirectly linked with the perceived organizational support (POS). As for 
organizational factors, which includes communication system in organization, management practice and policies, employees' empowerment, and organizational justice (Shah et al., 2010:170), are linked to perceived organizational support because those variables of organizational factors are the antecedents that related to POS (Allen et al., 2003:100). For attitude factors which are classified into job satisfaction and job stress (Shah et al., 2010:171), they are related with the perceived organizational support because the form of the organizational support is one of the factors that could contribute to job satisfaction or job stress, for example is recognition, freedom, etc. Lastly, organizational commitment is closely related with the perceived organizational support because organizational commitment is one of the important consequences of perceived organizational support (Beheshtifar and Herat, $2013: 307$ ).

Regarding the push factors that related to the perceived organizational support, then it could be assumed that perceived organizational support (POS) has an influence toward turnover intentions. Some research studies have proven this relationship. One of them is the study by Allen et al.,(2003 :114) that indicated that POS was significantly correlated negatively with turnover intentions in both samples and actual turnover in one sample, supporting the contention that individuals who perceive greater POS are less likely to withdraw.

A side from these findings of previous studies, researcher found that some of the budget hotel employees who have the intention to leave and the employees who were leaving during that time do not feel satisfied with the way organization treat them. They felt that the organization do not care about the employees' opinion regarding the management, and that the organization is lacking of justice toward the employees. These feeling confessed by the employees lead to the identification of problem in the way they perceive the organizational support. Based on this observation, supported by the theories and previous findings, researcher would like to study about the problem of turnover in this hotel by analyzing the perceived organizational support and its relationship with turnover intention. In order to support the research objectives, the following research questions were formulated to examine the relationship between perceived organizational support and the employees' turnover intentions.

\section{LITERATURE REVIEW}

\section{Perceived Organizational Support (POS)}

There have been several studies regarding this perceived organizational support (POS). The previous study by Allen et al. (2003:100) has summarized several types of antecedents related to POS from others' previous studies, including (1) perceptions of the organization, such as justice and politics (Cropanzano, Howes, Grandey \& Toth, 1997); (2) job conditions (Eisenberger, Rhoades \& Cameron, 1999); (3) supervisor support (Settoon, Bennett \& Liden, 1996).

Organizational behavior is a study utilized to recognizing, explaining, and developing the attitudes and behaviors of people within organizations (Kaifi and Noori, 2011:89). To develop the positive attitudes and behaviors of people in organization, organization needs to provide those people with support. Eisenberger et al.,(1986:501) defines "perceived organizational support as an employee's perception that the organization values his or her contribution and cares about the employee's wellbeing." Employees assess the degree to which their organization recognizes and rewards their effort, provides for their socio-emotional needs, and provides assistance in a time of need (Miao \& Kim, in Shelton : 55, 2013).

The study by Eisenberger et al.,(2004:212) mentioned several psychological outcomes of POS, which include the feeling of obligation, affective organizational commitment, performance-reward expectancies, and reduced stress. The feeling of obligation is strongly related with the norm of reciprocity that in this context is about the relationship between employer and employee. Because POS provides a broad and valued set of socio-emotional and impersonal resources to employees, in turn, employees will feel obligated to help the organization achieve its goals (Eisenberger et al., 1986). The obligated feeling arisen will lead to affective commitment to the organization where employees develop a strong emotional attachment to the organization (Rhoades et al.,2001). Since POS provides employees with favorable opportunities for rewards, in turn, POS will increase employees' expectancies that high performance will be rewarded by the organization or that is 
commonly known as performance-reward expectancies. POS provides supports in the form of emotional and also tangible supports to the employee, hence this treatment will help the employees to reduce their psychological strain in a stressful situation. With all these psychological outcomes of POS, they will contribute to the behavioral outcomes of increased performance and decreased withdrawal behavior.

\section{Turnover Intentions}

Turnover also adversely affects the administration of the organization, and staff turnover impact on the financial and social conditions of the working environment (Butali et al. in Amin \& Akbar, 2013:664). Relatedly with the direct and indirect costs of turnover intention, a study by Panwar et al.,(2012:84), found that high turnover rate could have several effects on organization such as the emerging cost of turnover, the loss of company knowledge, interruption of customer service, more turnovers for the remaining staffs, goodwill of the company is damaged, and the decreasing in efficiency.

Relating with employee turnover, turnover intention is a mental decision prevailing between an individual's approach with reference to a job to continue or leave the job (Jacobs \& Roodt in Hussain \& Asif, 2012:4). Turnover intentions are the instant connection to turnover behavior (Boles et al. in Hussain \& Asif, 2012:4). On the other words, turnover intention is a worker's act of thinking about quitting after they have experienced dissatisfaction, uncomfortable, and a worker's decrease of commitment to the organization etc (Lobburi, 2012:95). Turnover intention occurs when employees plan to leave their position or organizational leaders plan to remove employees from a position (Shelton, 2013:69).

Since in voluntary turnover employees decide by themselves to resign, Shah et al., (2010: 69) in his study have reviewed and summarized the variety of reasons for resigning, that can be classified into 4 factor, which are demographic factor, personal factor, push factor and pull factor. Demographic factor is the reason that related to age, marital status, number of children, education, etc. Personal factor mostly related to the aspects within the employee, such as health problem, family, social status, expectation, etc.

The other side, push factors are further classified into organizational factor, attitude factors, and organizational commitment. Organizational factor relates with communication system in organization, management practice and policies, and organizational justice. Attitude factor are differed into job satisfaction and job stress. Organizational commitment, according to Ongori in Shah et al. $(2010: 172)$ is an affective response to the whole organization and the degree of attachment or loyalty employees feel towards the organization. The last one, which is pull factors are considered as uncontrolled factors because it is out of the control of organization. These are factors that attract the employee to a new place of work, such as high salary, career advancement, new challenge and interesting work, job security, good location of company, etc.

\section{Perceived Organizational Support and Turnover Intentions}

Several previous studies have revealed that there is relationship between perceived organizational support (POS) and turnover intentions. Eisenberger et al.,(1990) suggested that individuals with high POS would be less likely to seek alternative employment in other organizations. The conducted in Uganda by Okello-Ouni (2004) in Tumwesigye (2010:944) investigated the relationship between POS and sales force turnover intentions, which reveal that turnover intentions and actual turnover of sales force are significantly and negatively related to POS. Another study by Lavelle et al.,(2009) in Tumwesigye (2010:944) found that POS positively predicted organizational citizenship behavior, in which, an employee who feels that an organization does not value his or her contribution will be inclined to leave that organization and so conversely, a person who feels that an organization offers him or her support by caring for his or her well being will be motivated to stay with that organization.

However, there're also some previous studies that found the effects of perceived organizational support on turnover are mediated through affective commitment (Rhoades et al.,2001), job satisfaction (Allen et al., 2003), and normative commitment (Maertz \& Gaertner, (2000) in Shelton, (2013:56)). The study by Tumwesigye (2010:949), also supports the previous finding that there's 
mediating role of affective commitment, normative commitment and continuance commitment in the relationship between POS and turnover intentions, that proved by the direct path coefficient between POS and turnover intention computed in the study that was not significant.

A study by Allen et al.,(2003) also resulted in similar way, which indicated that POS was significantly negatively correlated with turnover intentions in both samples and actual turnover in one sample, supporting the contention that individuals who perceive greater POS are less likely to withdraw. Supporting these previous findings is the study by Shelton (2013) that revealed a significant negative relationship between perceived organizational support and their propensity to leave. This study shows that the respondents' propensity to leave was higher when perceived organizational support was lower. Based on this findings, the researcher develop hypothesis for this study as follows :

1. H0 : There is no significant influence from Perceived Organizational Support (POS) toward Turnover Intentions of Budget Hotel Staffs in Jakarta.

2. H1: There is significant influence from Perceived Organizational Support (POS) toward Turnover Intentions of Budget Hotel Staffs in Jakarta

\section{METHODS}

\section{A. Research Design}

This research study addresses the problem of turnover intention in the budget hotels in Jakarta, which has a fluctuated turnover rate for the last 4 months (February to May 2017). The research study will involve measuring the variables and using statistical models to analyze the collected data. This study will be done by utilizing a cross-sectional study. Unit analysis for this research is the budget hotel staffs in Jakarta, Indonesia. The 156 respondents have been examined and presented in this chapter, which is divided into 13 sections. The respondent is taken based on the working period less than one year. The table below shows the detail of the number of staffs in each budget hotels.

\begin{tabular}{ccccc}
\multicolumn{2}{c}{ TABLE 2. TOTAL OF RESPONDENTS AROUND JAKARTA } \\
\hline \multirow{2}{*}{ No } & \multicolumn{1}{c}{ Sections } & $\begin{array}{c}\text { No. of staffs } \\
\text { Percentage }\end{array}$ & Percentage & Remarks \\
\hline 1 & South Jakarta - Hotel A & 8 & 5.13 & 3 star \\
2 & South Jakarta - Hotel B & 23 & 14.74 & 3 star \\
3 & South Jakarta - Hotel C & 16 & 10.26 & 3 star \\
4 & South Jakarta - Hotel D & 9 & 5.77 & 3 star \\
5 & South Jakarta - Hotel E & 8 & 5.13 & 2 star \\
6 & Central Jakarta - Hotel A & 21 & 13.46 & 3 star \\
7 & Central Jakarta - Hotel B & 24 & 15.38 & 3 star \\
8 & West Jakarta - Hotel A & 7 & 4.49 & 3 star \\
9 & West Jakarta - Hotel B & 4 & 2.56 & 2 star \\
10 & West Jakarta - Hotel C & 8 & 5.13 & 3 star \\
11 & West Jakarta - Hotel D & 11 & 7.05 & 3 star \\
12 & North Jakarta - Hotel A & 6 & 3.85 & 3 star \\
13 & North Jakarta - Hotel B & 11 & 7.05 & 2 star \\
\hline \multicolumn{7}{c}{ Total of Respondents } & $\mathbf{1 5 6}$ & $\mathbf{1 0 0 . 0 0}$ & \\
\hline
\end{tabular}

In this study, to determine the sample size, researcher used the table developed by Krejcie and Morgan (1970:608). Hence, according to the table, the acceptable sample size is 113 from 156 respondents. Since the number of the population was identified, hence researcher used the probability sampling, specifically the simple random sampling. The simple random sampling allows researcher to distribute the questionnaire to any budget hotel staffs without the need to stratify the sample or systematically choose the sample. Hence, with this sampling method, each population element has an equal chance of being, or not being, selected and that chance can't be influenced by the sample selector as it is made on a random basis (Brotherton,2008:169). 


\section{B. Data}

For this research, the 17-items version of SPOS is adapted from the questionnaire by Apodaca (2010:19). Eight of the 17-items ask questions concerning employee's perceptions of the degree to which the organization values their contributions, while the remaining nine items ask employees questions concerning actions the organization may take which could potentially affect the well-being of the employee (Apodaca,2010:19). For turnover intention followed to 3 similar measurement developed by Mobley, Mobley, Horner and Hollingsworth (1978:408-414) as it is used by Balogun \& Olowodunoye (2012:88). The scale measure employees thought of quitting, the intention to search for another job else where and the intention to quit that is the conceptualization of turnover intention (Hom \& Griffeth in Tumwesigye,2010).

TABLE 3. VARIABLES, INDICATOR AND MEASUREMENT SCALE

\begin{tabular}{|c|c|c|}
\hline Variable & Indicator & $\begin{array}{l}\text { Measurement } \\
\text { Scale }\end{array}$ \\
\hline \multirow{16}{*}{$\begin{array}{c}\text { Perceived } \\
\text { Organization } \\
\text { al Support }\end{array}$} & 1) The organization values my contribution to its well- being & \multirow{19}{*}{$\begin{array}{l}\text { Likert Scale with } 4-\text { points as } \\
\text { follows: } \\
-1=\text { strongly disagree } \\
2=\text { disagree } \\
-3=\text { agree } \\
4=\text { strongly agree }\end{array}$} \\
\hline & $\begin{array}{l}\text { 2) If the organization could hire someone to replaced me at a lower salary it } \\
\text { would do so. }\end{array}$ & \\
\hline & 3) The organization fails to appreciate any extra effort from me. & \\
\hline & 4) The organization strongly considers my goals and values. & \\
\hline & 5) The organization would ignore any complaint from me. & \\
\hline & $\begin{array}{l}\text { 6) The organization disregards my best interests when it makes decisions } \\
\text { that affect me. }\end{array}$ & \\
\hline & $\begin{array}{l}\text { 7) Help is available from the organization when I have a problem. } \\
\text { 8) The organization really cares about my well-being. }\end{array}$ & \\
\hline & $\begin{array}{l}\text { 9) The organization is willing to extend itself in order to help me perform my } \\
\text { iob to the best of mv ability. }\end{array}$ & \\
\hline & 10) Even if I did the best job possible, the organization would fail to notice. & \\
\hline & 11) The organization is willing to help me when I need a special favor & \\
\hline & 12) The organization cares about my general satisfaction at work. & \\
\hline & 13) If given the opportunity, the organization would take advantage of me. & \\
\hline & 14) The organization shows very little concern for me. & \\
\hline & 15) The organization cares about my opinions & \\
\hline & 16) The organization takes pride in my accomplishments at work. & \\
\hline & 17) The organization tries to make my job as interesting as possible. & \\
\hline \multirow{3}{*}{$\begin{array}{l}\text { Turnover } \\
\text { Intention }\end{array}$} & 1) I often think about quitting my present job & \\
\hline & 2) I will probably look for a new job in the next year & \\
\hline & 3) As soon as possible, I will leave the organization & \\
\hline
\end{tabular}

\section{Method}

However, before going through the inferential statistical analysis to test the hypothesis, researcher will first analyze the validity and reliability of the scales. Furthermore, Pearson Productmoment Correlation will be performed and then followed by the linear regression analysis and $R$ square analysis to study if there is significant relationship and influence between variables. Then, $F$ test will be conducted to test the hypothesis to see if there is significant influence of Perceived Organizational Support (POS) on Turnover Intentions of Budget Hotel Staffs in Jakarta, Indonesia.

\section{Scope of the Study}

The data collected from the budget hotel staffs in Jakarta will remain confidential and will not be published regarding the privacy concern of this hotel. As turnover is the common problem for hospitality industry, especially hotel, researcher found it important to study about the possibility of the causes. There have been several previous studies that address the problem of turnover in hospitality industry, however, the study that focuses in the budget hotels in Jakarta is still lacking. 


\section{RESULTS AND DISCUSSION}

\section{A. Validity and Reliability Analysis}

For the independent variable, Perceived Organizational Support (POS), it has 17 items on the questionnaire. However, after the data is collected and the validity analysis for this variable is conducted, researcher found that there are 2 items are not valid, since the correlation coefficient computed is below the value of correlation coefficient in $r$ table. Besides that, according to Guilford's measurement [31], these two items' correlation coefficient is categorized as low validity and very low validity that is not acceptable for further analysis. With this consideration, hence these 2 items are removed. Furthermore, the validity analysis is conducted again for the rest 15 items and the results shows that all the 15 items of POS variable are valid with significance of 0.05 . Each items fall into the category of good validity, except for item number 9 that falls into category of very good validity according to Guilford's measurement. The dependent variable, Turnover Intention (TI) has 3 items, and the validity analysis shows that all the items are valid in significance of 0.05 . These three items also considered to have very good validity based on Guilford's measurement. The result of the analysis is shown in Table 4.

TABLE 4. VALIDITY ANALYSIS OF ORGANIZATIONAL SUPPORT AND TURNOVER INTENTION

\begin{tabular}{|c|c|c|c|c|c|c|}
\hline No. & Variables & $\begin{array}{c}\text { Pearson } \\
\text { Correlation }\end{array}$ & $\begin{array}{c}\text { Pearson } \\
\text { Correlation } \\
\mathrm{r} \text { table }\end{array}$ & $\begin{array}{l}\text { Sig. }(2- \\
\text { tailed) }\end{array}$ & $\mathbf{N}$ & Note \\
\hline \multicolumn{2}{|c|}{ Perceived Organizational Support (X) } & \multicolumn{3}{|c|}{$\begin{array}{l}\text { df }=111 ; \text { sig. } \\
0.05 \text { (2-tail) }\end{array}$} & & \\
\hline 1 & The organization values my contribution to its well being & $.736^{* *}$ & 0.185 & .000 & 113 & Valid \\
\hline 2 & The organization fails to appreciate any extra effor from me & $.623^{* *}$ & 0.185 & .000 & 113 & Valid \\
\hline 3 & The organization strongly considers my goals and values & $764^{* *}$ & 0.185 & .000 & 113 & Valid \\
\hline 4 & The organization would ignore any complaint from me & $.622^{* *}$ & 0.185 & .000 & 113 & Valid \\
\hline 5 & $\begin{array}{l}\text { The organization disregards my best interests when it makes } \\
\text { decisions that affect me }\end{array}$ & $.731^{* *}$ & 0.185 & .000 & 113 & Valid \\
\hline 6 & Help is available from the organization when I have a problem & $.757^{* *}$ & 0.185 & .000 & 113 & Valid \\
\hline 7 & The organization really cares about my well-being & $.761^{* *}$ & 0.185 & .000 & 113 & Valid \\
\hline 8 & $\begin{array}{l}\text { The organization is willing to extend itself in order to help me } \\
\text { perform my job to the best of my ability }\end{array}$ & $.765^{* *}$ & 0.185 & .000 & 113 & Valid \\
\hline 9 & $\begin{array}{l}\text { Even if I did the best job possible, the organization would fail to } \\
\text { notice }\end{array}$ & $.809^{* *}$ & 0.185 & .000 & 113 & Valid \\
\hline 10 & The organization is willing to helo me when I need a special favor & $.723^{* *}$ & 0.185 & .000 & 113 & Valid \\
\hline 11 & The organization cares about my general satisfaction at work & $.739^{* *}$ & 0.185 & .000 & 113 & Valid \\
\hline 12 & The organization whos very little concern for me & $.774^{* *}$ & 0.185 & .000 & 113 & Valid \\
\hline 13 & The organization cares about my opinions & $.764^{* *}$ & 0.185 & .000 & 113 & Valid \\
\hline 14 & The organization takes pride in my accomplishments ar work & $.647^{* * *}$ & 0.185 & .000 & 113 & Valid \\
\hline 15 & The organization tries to make my job as interesting as possible & $.657^{* *}$ & 0.185 & .000 & 113 & Valid \\
\hline rno & $1(Y)$ & & & & & \\
\hline 1 & I often think about quitting my present job & $.854^{* *}$ & 0.185 & .000 & 113 & Valid \\
\hline 2 & I will probably look for a new job in the next year & $.872^{* *}$ & 0.185 & .000 & 113 & Valid \\
\hline 3 & As soon as possible, I will leave the organization & $.862^{* *}$ & 0.185 & .000 & 113 & Valid \\
\hline
\end{tabular}

The Cronbach's Alpha for 15 items of Perceived Organizational Support is .934. Moreover, 3 items of Turnover Intention have the Cronbach's Alpha for .828. Both reliability coefficients that is shown by the Cronbach's Alpha are acceptable according to cited by [32], who determined the critical point of reliability as 0.700 . Furthermore, according to [32], these coefficient of .934 and .828 are considered to have good reliability since the Cronbach's Alpha is greater than 0.8 . This good result of reliability test shows that this measurement has an internal consistency that these items tap only to this particular dimension. With this result of reliability analysis for both variables that have an acceptable value for reliability, hence it could be assumed that the data collected is reliable and 
can be used for further analysis.

TABLE 5. RELIABILITY ANALYSIS OF ORGANIZATIONAL SUPPORT AND TURNOVER INTENTION

\begin{tabular}{cccc}
\hline Variables & Cronbach's Alpha & N of Items & Note \\
\hline Perceived Organizational Support & .934 & 15 & Reliable \\
\hline Turnover Intention & .828 & 3 & Reliable \\
\hline
\end{tabular}

\section{B. Analysis of Employees' Perception on Organizational Support}

In order to find out about budget hotel employees' perception on the organizational support of budget hotels in Jakarta, researcher did the descriptive statistical analysis on the mean value of the items measuring Perceived Organizational Support. In the questionnaire, researcher used 4-point Likert scales with 1 represents "strongly disagree" and 4 represents "strongly agree". Furthermore, since the questionnaire consists of positively and negatively worded statement, hence in the Table 6 researcher separated the statements in order to be easier in interpreting the mean.

TABLE 6. EMPLOYEES' PERCEPTION ON ORGANIZATIONAL SUPPORT

\begin{tabular}{|c|c|c|}
\hline \multicolumn{3}{|l|}{ Table Descriptive Statistics } \\
\hline & $\mathbf{N}$ & Mean \\
\hline \multicolumn{3}{|l|}{ Positively Worded Statement } \\
\hline The organization values my contribution to its well being & 113 & 3.16 \\
\hline The organization strongly considers my goals and values & 113 & 2.91 \\
\hline Help is available from the organization when I have a problem & 113 & 3.04 \\
\hline The organization really cares about my well-being & 113 & 2.96 \\
\hline The organization is willing to extend itself in order to help me perform my job to the best of my ability & 113 & 3.05 \\
\hline The organization is willing to help me when I need a special favor & 113 & 2.96 \\
\hline The organization cares about my general satisfaction at work & 113 & 2.90 \\
\hline The organization cares about my opinions & 113 & 2.91 \\
\hline The organization takes pride in my accomplishments ar work & 113 & 3.06 \\
\hline The organization tries to make my job as interesting as possible & 113 & 2.96 \\
\hline \multicolumn{3}{|l|}{ Negatively Worded Statement } \\
\hline The organization fails to appreciate any extra effor from me & 113 & 2.11 \\
\hline The organization would ignore any complaint from me & 113 & 2.04 \\
\hline The organization disregards my best interests when it makes decisions that affect me & 113 & 2.09 \\
\hline Even if I did the best job possible, the organization would fail to notice & 113 & 2.01 \\
\hline The organization shows very little concern for me & 113 & 1.96 \\
\hline
\end{tabular}

For the positively worded statement, there are 10 valid items and the mean value resulted are ranging from 2.90 as the lowest and 3.16 as the highest value. With this range of mean value, it shows that the budget hotels employees mostly have a positive perception on the organizational support since the mean value have a tendency toward the value of 3 which means they agree with the positively worded statement regarding the organizational support. Simply said, they agree that the organization provides support for them.

The lowest value for the positively worded statement is 2.90 that is generated from statement "The organization cares about my general satisfaction at work." This might show that there are some few employees who are disagree with this statement because they feel the organization do not care enough for their general satisfaction at work. However, the highest value is 3.16 for the statement "The organization values my contribution to its well- being." It shows that most of the employees feel that their works are appreciated by the organization.

Otherwise, for the 5 valid negatively worded statements, the mean value are ranging from 1.96 as the lowest until 2.11 as the highest. This value has a tendency to the value of 2 which is disagree, 
hence, it could be assumed that most of the employees are disagree with these negatively worded statement which states that the organization do not give good support, acknowledgement or appreciation toward the employees.

Since the highest value in these negatively worded statements is 2.11 for "The organization fails to appreciate any extra effort from me", some employees might feel that their extra effort is not seen nor appreciated by the organization. However, with the lowest value of 1.96 for "The organization shows very little concern for me", it shows that the employees feel that the organization has given enough concern for them. These mean values resulted for positively and negatively worded statements, both are showing that employees agreed that organization gives good support for them, so it means they perceived the organizational support in a good way.

TABLE 7. EMPLOYEES' PERCEPTION ON TURNOVER INTENTION

Descriptive Statis tics

\begin{tabular}{lll}
\hline & $\mathbf{N}$ & Mean \\
\hline I often think about quitting my present job & 113 & 2.12 \\
\hline I will probably look for a new job in the next year & 113 & 2.38 \\
\hline As soon as possible, I will leave the organization & 113 & 1.88 \\
\hline Valid N (listwise) & $\mathbf{1 1 3}$ & \\
\hline
\end{tabular}

The mean values for all three statements measuring turnover intention are ranging from 1.88 as the lowest and 2.38 as the highest. These mean values have a tendency toward the value of 2 which representing disagreement toward the statements. Hence, from the results, it could be assumed that most of the budget hotel employees do not have the intention to leave this hotel in the meantime. However, with the highest score of 2.38 for statement "I will probably look for a new job in the next year", it could be assumed that there might be some employees who are planning to leave the organization in the future.

\section{Relationship between Perceived Organizational Support and Turnover Intention}

Pearson Product-moment correlation was performed to analyze the relationship between the independent variable (POS) and dependent variable (TI).

\begin{tabular}{|c|c|c|c|}
\hline & & $\begin{array}{c}\text { Perceived } \\
\text { Organizational } \\
\text { Support } \\
\end{array}$ & $\begin{array}{l}\text { Turnover } \\
\text { Intention }\end{array}$ \\
\hline \multirow{3}{*}{$\begin{array}{l}\text { Perceived } \\
\text { Organizational } \\
\text { Support }\end{array}$} & Pearson Correlation & 1 & $-.542 * *$ \\
\hline & Sig. (2-tailed) & & .000 \\
\hline & $\mathrm{N}$ & 113 & 113 \\
\hline \multirow{3}{*}{$\begin{array}{l}\text { Turnover } \\
\text { Intention }\end{array}$} & Pearson Correlation & $-.542 * *$ & 1 \\
\hline & Sig. (2-tailed) & .000 & \\
\hline & $\mathrm{N}$ & 113 & 113 \\
\hline
\end{tabular}

The results shows that there is a negative relationship between these variables of perceived organizational support (POS) and turnover intention (TI) that is presented by the correlation coefficient $r=-.542$, with the $\mathrm{p}$ value of .000 that is less than .05 or even .001 , which shows that this relationship is significant. With the correlation coefficient of -.542 , it could be assumed that the relationship between perceived organizational support and turnover intention is moderate (Sugiyono, 2010).

With this negative relationship, it shows that if employees receive well support from the organization then they will prefer to stay with the organization that will reduce the turnover intention. 
Hence, it could be assumed that when the organizational support is perceived high by the employee, then their intention to leave will be low. By this correlation analysis, the research question 1 has been answered. This result is as expected since the previous research has shown that POS is negatively related to turnover intentions (Tumwesigye, 2010; Allen, et al., 2003).

\section{The Degree of Perceived Organizational Support's Influence toward Turnover Intention}

From the simple regression analysis, the coefficient of determination or commonly known as $R$ square is also attained. Table 9 shows that the model of this analysis has achieved the Adjusted $R$ Square of .288. This means $28.8 \%$ of variance in turnover intention is explained by perceived organizational support while the other $71.2 \%$ is influenced by other factor.

Table 9. Coefficients of Determinant

\begin{tabular}{|c|c|c|c|c|}
\hline \multirow{2}{*}{ Model } & \multirow{2}{*}{$\mathrm{R}$} & $\mathrm{R}$ & Adjusted & Std. Error of \\
\hline & & Square & R Square & the Estimate \\
\hline 1 & $.542^{\mathrm{a}}$ & .294 & .288 & 1.87851 \\
\hline
\end{tabular}

a. Predictors: (Constant), total POS

It could be assumed that in the budget hotels staffs in Jakarta, perceived organizational support is not the main reason of the employee to leave the organization that makes the fluctuation in the turnover rate. Other factors that are not considered in this research could be counted as the predictors of the turnover intention. Perceived organizational support is indirectly linked with the push factor for turnover, hence the other factor influencing the turnover intention could be the demographic factor, personal factor or pull factor (Shah et al., 2010:169). It's also possible that the other factor contributed to influence the turnover intention that is not addressed in this research, is the variable in push factor itself, such as the organizational factor, attitude factor, and organizational commitment (Shah et al.,2010:169). However, since the perceived organizational support is not the main predictor for turnover intention, then it could be assumed that employees of budget hotel in Jakarta perceived organizational support given by the budget hotel in Jakarta, in a good way.

\section{E. Influence of Perceived Organizational Support toward Turnover Intention}

Simple linear regression was performed to measure the influence on turnover intention with perceived organizational support as the predictor that will be the answer for the second research question. This table below show the result of the simple linear regression analysis that provides the estimated coefficient of independent variable and the significant values. Table 8 shows that the simple linear regression analysis, it is discovered that the influence from perceived organizational support to turnover intention is negative, which means the higher the POS, the lower the TI will be.

TABLE 10. REGRESSION ANALYSIS OF POS ON TI ANOVA $^{\mathrm{a}}$

\begin{tabular}{|c|c|c|c|c|c|c|}
\hline \multirow{2}{*}{ Model } & & \multicolumn{2}{|c|}{$\begin{array}{l}\text { Unstandardized } \\
\text { Coefficients }\end{array}$} & \multirow{2}{*}{$\begin{array}{c}\begin{array}{l}\text { Standardized } \\
\text { Coefficients }\end{array} \\
\text { Beta }\end{array}$} & \multirow{2}{*}{$\mathrm{t}$} & \multirow{2}{*}{ Sig. } \\
\hline & & $\mathrm{B}$ & $\begin{array}{c}\text { Std. } \\
\text { Error }\end{array}$ & & & \\
\hline \multirow[t]{2}{*}{1} & (Constant) & 13.770 & 1.100 & & 12.521 & .000 \\
\hline & POS & -.165 & .024 & -.542 & -6.800 & .000 \\
\hline
\end{tabular}

Hence, it could be assumed that if the employer would like to reduce the turnover rate, they could do it by improving their support on employee by showing that they care about the employee's well-being. This result is consistent with the theory of organizational support theory (Eisenberger et al., 1986), that overall state the similar idea of employees who are being treated well 
by the employer in the form of support and appreciation will feel obligated to the organization and less likely to leave the organization. This result is also in line with the previous findings that found negative relationship between perceived organizational support and turnover intention (Tumwesigye (2010), Shelton (2013).

\section{F. Hypothesis Testing}

To test the hypothesis, researcher used $F$-test by comparing the $F$-value. The $F$-value for this study is also attained from the simple linear regression analysis conducted through computer program SPSS Statistics 21. This table below shows the F-value calculated for this relationship.

TABLE 11. $F$ TEST RESULT

\begin{tabular}{llccccc}
\hline Model & & Sum of Squares & df & Mean Square & F & Sig. \\
\hline \multirow{2}{*}{1} & Regression & 163.169 & 1 & 163.169 & 46.239 & $.000^{\mathrm{b}}$ \\
\cline { 2 - 7 } & Residual & 391.698 & 111 & 3.529 & & \\
\cline { 2 - 7 } & Total & 554.867 & 112 & & & \\
\hline
\end{tabular}

a. Dependent Variable: total TI

b. Predictors: (Constant), totalPOS

The $F$-statistic, or $F$-value calculated for this study is 46.239 . With 1 and 111 degree of freedom, then the $F$-critical value attained from the $F$-table is 3.9266 . These $F$-values are further compared to test the hypothesis. The comparison results that $F$-statistic is greater than the $F$-critical value (46.23 >3.92), significance 0.00 less than 0.05 then the null hypothesis is rejected and the alternative hypothesis is accepted.

TABLE 12. HYPOTHESIS SUMMARY

\begin{tabular}{llc}
\hline \multicolumn{1}{c}{ Hypothesis } & Result \\
\hline $\mathrm{H}_{0}:$ & $\begin{array}{l}\text { There is no significant influence from Perceived Organizational Support (POS) on Turnover } \\
\text { Intentions of budget hotel staffs in Jakarta }\end{array}$ & Not Supported \\
& & $\begin{array}{c}\text { Supported (F }= \\
46.239, \text { sig 0.000) }\end{array}$ \\
\hline $\mathrm{H}_{1} \quad \begin{array}{l}\text { :There is significant influencefrom Perceived Organizational Support (POS) on Turnover } \\
\text { Intentions of budget hotel staffs in Jakarta }\end{array}$ & \\
\hline
\end{tabular}

\section{CONCLUSION}

\section{A. The Relationship between Perceived Organizational Support and Turnover Intention}

The results show that there is negative relationship between perceived organizational support and turnover intention. The negative relationship is existed in the moderate correlation. With this negative relationship, then it could be assumed that when perceived organizational support is high, the turnover intention is low. It is expected, as if employees perceived that the organizational support is good and they feel satisfied with the way the organization care to their well-being, then they will prefer to stay with the organization.

\section{B. The Influence of Perceived Organizational Support toward Turnover Intention}

Moreover, besides having the negative relationship, perceived organizational support (POS) is also found to have negative influence on turnover intention (TI). It means that by increasing their organizational support, the organization could reduce the turnover intention of their employees. This finding could be useful for the budget hotels staffs in order to reduce their employees' turnover intention. 


\section{The Degree of the Influence of Perceived Organization Support on Turnover Intention}

However, even though the relationship and the influence are both significant, the result of the adjusted R-square showed that the influence given by POS on turnover intention only counted for $28.8 \%$. This number is considerably small. Hence, it could be assumed that although perceived organizational support has an influence to minimize the turnover intention, the influence given is not big. It shows that the turnover intention of the budget hotels staffs in Jakarta is not solely determined by how the the budget hotels staffs perceive the organizational support but it might be influenced by other factors that are not addressed in this study. As a result of study, perceived organizational support is not the main problem for the budget hotels staffs in Jakarta. They perceived the organizational support provided by the organization in a good way that is confirmed by the mean analysis for the perceived organizational support. Hence, perceived organizational support doesn't become the main predictor for their turnover. Moreover, based on the mean analysis of turnover intention, the budget hotels staffs in Jakarta mostly do not have the intention to leave the organization. However, the budget hotels staffs in Jakarta could improve their organizational support for their employees, since it is significantly related negatively to turnover intention. By improving and enhancing the organizational support, they can reduce the turnover rate and further they can stabilize the turnover rate in their organization.

\section{RECOMMENDATION}

This study has demonstrated the negative influence POS had on turnover intention and it is identified that the budget hotels staffs perceived the organizational support in a good way. However, the management of budget hotels in Jakarta could improve their organization support toward the employees to be able to reduce the turnover. The budget hotels could improve their support especially in some points of the organizational support that is still lacking in the employees' perception, which are regarding the employees' general satisfaction and appreciation on their extra effort. Not only improving their support, The budget hotels should also be able to maintain their good support to the employees that they have been doing this whole time. By maintaining and improving organizational support, employees will receive better support and will likely to stay within the organization that makes organization to have better benefits and to be saved from the costs of turnover. This research also recommended that employers take steps such as maintaining appropriate remuneration and promotion prospects, as well as improved workplace efficiency, in order to better retain in-demand employees.

However, although the influence of POS toward turnover intention is significant, the influence shown by the adjusted R-square is considerably small. Regarding that, researcher gives recommendation to other researcher for next study to include other variables beside perceived organizational support (POS) to be able to find out about the most influencing factors on turnover intention. The other variables possible for influencing turnover could be the variables of push factors itself such as organizational factor (organizational justice, benefits, etc.), attitude factors (job satisfaction and job stress), and organizational commitment (affective commitment, continuance commitment, and normative commitment). It could also be the pull factor or even the demographic and personal factor (Shah et al., 2010). Besides including other variables, the mediating variables between POS and turnover intention, such as organizational commitment and job satisfaction could also be considered for the next study (Rhoades et al., 2001; D.G. Allen et al., 2003; Tuwmesigye, 2010).

Another recommendation for further study is related with the unit of analysis. This research only study about the budget hotels staffs in Jakarta, hence, for further study, it would be better to cover all star hotels not only for budget hotels. By studying several star hotels, the next research then could compare and see if the same condition applies for those different hotels between problem in the budget hotels staffs and star hotels in Jakarta. 


\section{REFERENCES}

Allen et al., The Role of Perceived Organizational Support and Supportive Human Resource Practices in the Turnover Process. Journal of Management. 29(1) : 99-118. (2003)

Amin, Z., and Kharissa Pratiwi Akbar., "Analysis of Psychological Well- being and Turnover Intentions of Hotel Employees: An Empirical Study," International Journal of Innovation and Applied Studies. 3(3) : 662-671.( 2013)

Arunothaipipat, Rosamarin.," Human Resource Management of Small Independent Hotels: A Case Study of Cha-am Beach, Phetchaburi, Thailand," SIU Journal of Management. Special Supplement 1 : 88100.(2013)

Apodaca, Steven P., "The Mediating Effect of Perceived Organizational Support on Espoused Safety Attitudes: A Field Study (Master's Thesis)," Angelo State University.(2010).

Balogun, Anthony G., and Stella A. Olowodunoye.," Psychological Factors As Predictors of Turnover Intention Among Employees of Post- Consolidation Banks in Nigeria," European Scientific Journal. 8(20) : 81-95.(2012)

Brotherton, B., "Researching Hospitality and Tourism: A Student Guide," London: Sage Publications Ltd. (2008)

Colakoglu et al,. "The Effects of Perceived Organizational Support on Employees' Affective Outcomes: Evidence from the Hotel Industry". Tourism and Hospitality Management. 16(2) : 125-150. (2010)

Colliers Quarterly. Jakarta Hotel. Q3. 2017. http://www.colliers.com/-/ Beheshtifar, M., and Batol Hosseini Herat., "To Promote Employees Commitment via Perceived Organizational Support," International Journal of Academic Research in Business and Social Sciences. 3(1) : 306313.(2013).media/files/marketresearch/apac/indonesia/q3-2017-colliersquarterly-jakartahotel.pdf?la=en-gb. Retrieved 09 November 2017

Cropanzano, Howes, Grandey \& Toth.,"The relationship of organizational politics and support to work behaviors, attitudes and stress," Journal of Organizational Behavior.18, 159-180. (1997).

Demir, Cengiz et al., "Relationship between Employee Turnover and the Location of Hotels: The Case of Kuşadasi and Izmir in Turkey," Journal of Yaşar University. 2(5) : 477-487.(2007).

Eisenberger, R., Rhoades, L., Cameron, J., "Does pay for performance increase or decrease perceived selfdetermination and intrinsic motivation?," Journal of Personality and Social Psychology, 77(5), 10261040. (1999).

---------., Huntington, R., Hutchison, S., Sowa, D.,’Perceived Organizational Support. Journal of Applied Psychology," 71(3) : 500-507.(1986)

---, R., Stinglhamber, F., Vandenberghe, C., Sucharski, I. L., \& Rhoades, L. ,’Perceived supervisor support: Contributions to perceived organizational support and employee retention". Journal of Applied Psychology, 87: 565-573. (2002)

---------, R., Cummings, J., Armeli, S., \& Lynch, P., "Perceived organizational support, discretionary treatment, and job satisfaction". Journal of Applied Psychology, 82: 812-820.(1997)

Guilford, J.P.. "New Standards for Test Evaluation”. Educational and Psychological Measurement. 6 : $427-$ 439. (1946)

Hussain, T., and S. Asif., "Is Employees' Turnover Intention Driven by Organizational Commitment and Perceived Organizational Support?," Journal of Quality and Technology Management. 8(2):01-10.(2012)

Kaifi, Belal A., and Selaiman A. Noori., "Organizational Behavior: A Study on Managers, Employees, and Teams," Journal of Management Policy and Practice. 12(1) : 88-97.(2011)

Krejcie, Robert V., and Daryle W. Morgan.," Determining Sample Size for Research Activities. Educational and Psychological Measurement," 30:607-610.(1970)

Limyothin, P., and Charlee Trichun., "The Structural Equation Model of Factors Influencing the Hotel Staff in Thailand's Intention to Quit," International Journal of Human Resource Studies. 2(3):22-35. doi:10.5296/ijhrs.v2i3.2078.(2012).

Lobburi, P., "The Influence of Organizational and Social Support on Turnover Intention in Collectivist Contexts," The Journal of Applied Business Research. 28(1) : 93-104.(2012).

Mobley,W H., S O Horner and A T Hollingsworth. "An Evaluation of precursors of hospital employee turnover," Journal of Applied Psychology. 408-414.(1978)

Panwar et al., "High Staff Turn Over in Hotel Industry, Due to Low Remunerations and Extended Working Hours!!! VRSD,” International Journal of Business \& Management Research. 2(3):81-89.(2012).

Riyadi, Agus and Radzi,S.M., "The Moderating Effect of Environmental Variables on Business Strategy and Performance of Hotels in Batam Island, Indonesia," Current Issues in Hospitality and Tourism Research and Innovations - Proceedings of the International Hospitality and Tourism Conference (IHTC). CRC Press/Belkama. 189-194,( 2012) 
Rhoades, L., Eisenberger, R. and Armeli, S., "Affective commitment to the organization: the contribution of perceived organizational support", Journal of Applied Psychology, Vol. 86, pp. 825-836. (2001)

-----------, L., and Robert Eisenberger., "Perceived Organizational Support: A Review of the Literature, ” Journal of Applied Psychology. 87(4) : 698-714. doi: 10.1037//0021-9010.87.4.698.(2002).

Sekaran, Uma. "Metodologi Penelitian untuk Bisnis". Jakarta: Salemba Empat.( 2006)

Settoon, RP.,Bennett,N. and Liden,RC., "Social exchange in organizations: perceived organizational support, leader-member exchange and employee reciprocity," Journal of Applied Psychology, 81, 219227.(1996)

Singapore Highlights., https://apac.aonhewitt.com/home/about/media-room/press-releases/october-november2016 Retrieved 09 November 2017.

Shelton, Markus.,"Impact of Perceived Organizational Support on Cyber Security Practitioners'Turnover Intentions (Doctoral Dissertation)," Walden University. (2013)

Shamsuzzoha, and Rezaul Hasan Shumon.," Employee Turnover-a Study of its Causes and Effects to Different Industries in Bangladesh," International Journal of Humanities and Social Science. Special Issue:6468.(2010)

Shah, et al., "Measuring Push, Pull and Personal Factors Affecting Turnover Intention: A Case of University Teachers in Pakistan," Review of Economic \& Business Studies. 3(1):167-192.(2010)

Tumwesigye, Godfrey., "The Relationship between Perceived Organisational Support and Turnover Intentions in a Developing Country: The Mediating Role of Organisational Commitment," African Journal of Business Management. 4(6):942-952.(2010) 